\title{
OSMOTIC AND CONVECTIVE DRYING OF STRAWBERRIES: EFFECTS OF EXPERIMENTAL PARAMETERS ON THE DRYING KINETICS, COLOR AND REHIDRATATION
}

\author{
OSMOTSKO I KONVEKTIVNO SUŠENJE JAGODE: UTICAJ \\ EKSPERIMENTALNIH PARAMETARA NA KINETIKU SUŠENJA, \\ BOJU I REHIDRATACIJU
}

\author{
Ivan PAVKOV*, Zoran STAMENKOVIĆ*, Milivoj RADOJČIN ${ }^{*}$, Kešelj KRSTAN*, \\ Vojislava BURSIĆ ${ }^{*}$ Siniša BIKIĆ ${ }^{* *}$, Vangelče MITREVSKI ${ }^{* * *}$, \\ *Faculty of Agriculture, University of Novi Sad,TrgDositejaObradovića 8, 21000 Novi Sad, Serbia \\ ${ }^{* *}$ Faculty of Technical Science, University of Novi Sad, BulevarcaraLazara6, 21000 Novi Sad, Serbia \\ ${ }^{* * * *}$ Faculty of Technical Sciences, University "St. KlimentOhridski” 7000 Bitola, Macedonia \\ e-mail address: ivan.pavkov@polj.uns.ac.rs
}

\begin{abstract}
The objective of this research was to investigate the influence of osmotic dehydration as a pre-treatment to the air drying of strawberries. Fresh, untreated strawberries were sliced and dried in a sucrose solution at a temperature of $50{ }^{\circ} \mathrm{C}$ and concentrations of 50 and $65^{\circ} \mathrm{Bx}$. After osmotic dehydration, the slices were dried in a thin layer at air temperatures of 60,70 and $80{ }^{\circ} \mathrm{C}$, and an air velocity of $1 \mathrm{~m} / \mathrm{s}$.

After osmotic dehydration, the moister content and solid gain at a sucrose solution concentration of $55^{\circ} \mathrm{Bx}$ were $3.44 \mathrm{~g}_{\mathrm{w}} / \mathrm{g}_{\mathrm{dm}}$ and $0.062 \mathrm{~g}_{\mathrm{dm}} / \mathrm{g}$, respectively. However, the moister content and solid gain in at a sucrose solution concentration of $65^{\circ} \mathrm{Bx}$ were 4.08 $g_{w} / g_{d m}$ and $0.0944 g_{d m} / g\left(65^{\circ} \mathrm{Bx}\right)$, respectively. The effective moisture diffusivity of air drying varied from $1.57 \times 10^{-9}$ to $4.43 \times 10^{-10}$ $\mathrm{m} / \mathrm{s}^{2}$, increasing with an increase in air temperatures and decreasing with an increase in pretreatment source concentrations. Lower air temperatures exert a positive influence on the rehydration time. A shorter air drying process positively affects the total changes in colour. The impact of pretreatment on colour changes in strawberries was not recorded after drying.
\end{abstract}

Keywords: strawberry, osmotic dehydration, air drying, rehydration, color.

\section{REZIME}

Obavljeno je eksperimentalno sušenje listića sveže jagode. Istraženo je osmotsko sušenje i njegov uticaj kao predtretma na konvektivnom sušenju. Urađena su merenja kinetike osmotskog i konvektivnog sušenja. Analiziran je uticaj parametra procesa na brzinu sušenja, rehidrataciju i promenu boje. Osmotsko sušenje je obavljeno u rastvoru saharoze, dve koncentracije 55 i $65^{\circ} B x$ i temperature $50^{\circ} \mathrm{C}$. Posle osmotskog sušenja listići jagode su dosušivani u konvektivnoj sušari na temperaturama vazduha $60,70 i$ $80^{\circ} \mathrm{C}$ i brzini vazduha $1 \mathrm{~m} / \mathrm{s}$.

Sniženje vlažnosti listića jagode i povećanje suve materije, u odnosu na početnu, posle osmotskog sušenja je iznosilo $3,44 g_{w} / g_{s m} ; 0,062 g_{s m} / g$ za koncentraciju rastvora $55^{\circ} B x$ i $4,08 g_{w} / g_{s m} ; 0,0944 g_{s m} / g$ za65 $\mathrm{Bx}$. Sa porastom koncentracije rastvora povećava se sniženje vlažnosti i povećanj esuve materije. Koeficijent difuzije vlage tokom konvektivnog sušenja za sve eksperimente je od 1,57 × $10^{-9}$ do $4,43 \times 10^{-10} \mathrm{~m} / \mathrm{s}^{2}$ sa porastom temperature vazduha raste i njegova vrednost. Na koeficijent difuzije vlage tokom konvektivnog sušenja utiče osmotsko sušenje kao predtretman. Uzorci koji suprethodno sušeni sa višo mkoncentracijom saharoze imaju manji koeficijent difuzije vlage. Poređenjem vremena sušenja od početne vlažnosti sveže jagode do vlažnosti od $20 \%$ nema značajnih razlika u brzini sušenja između netretiranih i tretiranih uzoraka. Blaga prednost je na strani netretiranih uzoraka. Brzina rehidratacije zavisi od predtretmana, brže se rehidriraju netretirani uzorci od tretiranih. Kraće vreme konvektivnog sušenja utiče na manju promenu boje konačnog proizvoda.

Ključne reči: jagoda, osmotsko sušenje, konvektivno sušenje, redehidratacija, boja.

\section{INTRODUCTION}

The strawberry is a very popular seasonal fruit available in Serbia during the spring and early summer. Compared to other fruits, the strawberry is highly appreciated for excellent organoleptic properties such as red color, fine texture, and unique flavor and taste. Furthermore, strawberries are a good source of ascorbic acid and other antioxidants. They have a very short postharvest shelf life, which affects the market potential and consumer access. Because strawberries are a seasonal crop, most of the harvested fruits in Serbia are preserved by freezing or by processing into concentrated juices, jams, jellies, puree and marmalades. Strawberries are mainly used in dairy products, or as ingredients in biscuits, cookies, etc. Dried strawberry fruits are perfect as components of fruit and herbal teas, mueslis and desserts, as well as healthy dried snacks. They can be preserved by drying processes such as air drying, osmotic dehydration with air drying, microwave and freeze drying (Adak et al., 2017; Agnieszka and Lenart, 2010; Piotrowski et al., 2004; Ferrando and Spiess, 2003).

Previous research, conducted over the past decade, suggests that osmotic dehydration used in fruit processing exerts a beneficial effect on both decreasing the water content and increasing the dry matter content, thus resulting in appealing and tasty products (Radojčin et al., 2010). Osmotic drying used as a pretreatment in the fruit drying process reduces draying rate values during air and microwave drying (Pavkov et al., 2010; 
Piotrowski et al., 2004). Rehydration can be regarded as an evaluation on the change in the material structure caused by drying. It is generally accepted that the degree of rehydration is dependent on the degree of cellar and structural disruption. Agnieszka and Lenart (2010) found that sorption isotherms and adsorption rates decrease in the case freeze-dried strawberries that were osmotically dehydrated in a sucrose and glucose solution. Same authors found that freeze-dried strawberries, after previous osmotic pretreatments, were characterized by lower water contents after $120 \mathrm{~min}$ of rehydration, compared to fruit not subjected to osmotic dehydration.

A combination of osmotic dehydration and convective drying appears as a good drying procedure for fruit drying, characterized by reasonable energy consumption as well as a favorable shelf life and high quality of dried products. The purpose of this study is to examine the kinetics of drying fresh strawberries and strawberries pretreated using osmotic dehydration. A detailed analysis of the influence of osmotic dehydration on the drying curves, drying rates, rehydration and color changes in strawberries will be presented in this study.

\section{Nomenclature:}

$\begin{array}{ll}\mathrm{a}^{*}, \mathrm{~b}^{*} & \text { - color coordinates } \\ c\left({ }^{\mathrm{O}} \mathrm{Bx}\right) & \text { - sucrose concentration } \\ m(\mathrm{~g}) & \text { - mass, } \\ \mathrm{t}(\mathrm{h}, \mathrm{min}) & \text { - drying time } \\ D_{a}\left(\mathrm{~m} / \mathrm{s}^{2}\right), & \text { - pre-exponential Arrhenius factor } \\ D_{e}\left(\mathrm{~m} / \mathrm{s}^{2}\right), & \text { - moisture diffusivity coefficient } \\ \mathrm{L}^{*}(-) & \text { - color brightness } \\ \mathrm{MR}(-) & \text { - moisture ratio } \\ \mathrm{R}(\mathrm{kJ} / \mathrm{mol}) & \text { - universal gas constant } \\ \mathrm{SG}\left(\mathrm{g}_{\mathrm{d} . \mathrm{b}} / \mathrm{g}\right) & \text { - solid gain } \\ T\left({ }^{\circ} \mathrm{C}, \mathrm{K}\right) & \text { - temperature, } \\ \mathrm{X}\left(\mathrm{g}_{\mathrm{w}} / \mathrm{g}_{\mathrm{d} . b .}\right) & \text { - moisture content on dry basis } \\ \mathrm{Y}(\mathrm{m}) & \text { - half thickness of strawberries slices } \\ \Delta \mathrm{E}(-) & \text { - total color change }\end{array}$

Greek symbols

$\Delta \quad$ - change of parameter value,

$\begin{array}{ll}\text { Subscripts } & \\ \text { d.b. } & \text { - dry basis } \\ \text { eq } & \text { - equilibrium } \\ \text { o } & \text { - initial value } \\ \text { r } & \text { - rehydrated } \\ \text { t } & \text { - value at the } \mathrm{t} \text { - time } \\ \text { w } & \text { - water }\end{array}$

\section{MATERIAL AND METHOD}

Fresh strawberry ('Jolly') were obtained from a local producer (Intersad, Rumenka, Serbia) and stored in a refrigerator at $4^{\circ} \mathrm{C}$ until used. All the fruit samples were at the beginning of technological ripeness with a $\mathrm{pH}$ value of 3.24. Strawberries of the following uniform size were selected for the experiment: length $(31.55 \pm 2.75 \mathrm{~mm})$, width $(30.1 \pm 3.28 \mathrm{~mm})$, thickness $(25.9 \pm 2.78 \mathrm{~mm})$, mass $11.75 \pm 2.68 \mathrm{~g}$ and moisture content $87.14 \% \pm 0.49 \%$ (wet basis). The average values of the main physical properties of fresh strawberries were measured on a random sample of 20 fruits.

After washing in tap water and removing the external impurities, strawberries were cut into $4.0 \pm 0.5 \mathrm{~mm}$ thick slices along the longitudinal axis. The slices were dipped in a $5 \%$ ascorbic acid solution at room temperature $\left(\approx 25^{\circ} \mathrm{C}\right)$ for $3 \mathrm{~min}$.

The strawberries fruits for drying were prepared in two following manners:

- untreated (placed fresh into a convective dryer), and

- pretreated (strawberries were placed into a convective dryer after osmotic dehydration).

Osmotic dehydration was carried out in $55^{\circ} \mathrm{Bx}$ and $65^{\circ} \mathrm{Bx}$ sucrose solutions at a temperature of $50{ }^{\circ} \mathrm{C}$ with steering for $2 \mathrm{~h}$. The mass ratio of raw material to osmotic solution was 1:4. Every 30 minutes, three slices were taken from the osmotic solution. It is assumed that these samples represent the mean changes in the moisture content (water loss, WL) and an increase in the dry matter (solid gain, SG) during osmotic dehydration in the period under consideration. The moisture content and solid gain of strawberries were measured using the thermogravimetric method (105 $\left.{ }^{\circ} \mathrm{C}, 24 \mathrm{~h}\right)$, a laboratory dryer, Sterimatic ST-11, "Instrumentaria”, Zagreb and analytical scales KERN 440-33N (0 - $200 \mathrm{~g}, 0.01 \mathrm{~g} \pm 0.02 \mathrm{~g})$ in three replicates. The moisture content $\left(\mathrm{X}_{\mathrm{t}}\right)$ and the increase in dry mater (solid gane, $\mathrm{SG}$ ) at a specific time were calculated using the following equations:

$$
\begin{aligned}
X_{t} & =\frac{m_{t}-m_{d . b .}}{m_{d . m .}} \\
S G & =\frac{m_{d . b .(t)}-m_{d . b .(o)}}{m_{o}}
\end{aligned}
$$

The air drying experiments of untreated and pretreated strawberries were carried out at air temperatures of 60,70 and 80 ${ }^{\circ} \mathrm{C}$ and an air velocity of $1.0 \mathrm{~m} / \mathrm{s}$. The samples were placed on trays in a thin layer in an experimental convective dryer "IVA 2" (Pavkov et al., 2009). Using the experimental dryer, mass changes in the strawberry samples were continuously recorded, as well as air temperatures. The specific mass of strawberry slices on trays was $1.56 \mathrm{~kg} / \mathrm{m}^{2}$. Each sample utilized in the experiment had a approximate mass of $800 \mathrm{~g}$. The amount of water removed during the air drying process was recorded at a 5minute interval using a mass sensor integrated in the drying chamber (with an accuracy of $\pm 1 \mathrm{~g}$ ). The drying process continued until the equilibrium moisture content was reached. The drying data obtained were expressed as the moisture content relative to the dry basis $\left(\mathrm{X}_{\mathrm{t}}\right)$, and the moisture ratio (MR) in relation to the drying time.

The moisture ratio (MR) of the drying samples at any time was calculated using to the following equation:

$$
M R=\frac{X_{t}-X_{e q}}{X_{o}-X_{e q}}
$$
2004):

The drying rate was calculated as follows (Piotrowski et al.,

$$
\frac{\Delta X_{t}}{\Delta t}=\frac{X_{t+\Delta t}-X_{t}}{\Delta t}
$$

The effective moisture diffusivity $\left(D_{e}, \mathrm{~m} / \mathrm{s}^{2}\right)$, which is generally accepted to be an important kinetics parameter, describes the transport of moisture from the material to the surroundings in the falling rate period and can be defined by the Fick's second law for an infinite plate (Carnk, 1995). the Fick's equation incorporates the uniform initial moisture distribution, negligible external resistance, constant diffusivity, constant temperature and negligible shrinkage. The following solution of the equation is used for long drying periods: 


$$
\begin{aligned}
& M R=\frac{8}{\pi^{2}} \sum_{\mathrm{n}=1}^{\infty} \frac{1}{\mathrm{n}} \exp \left(-\frac{n^{2} \pi^{2} \cdot D_{e}}{Y^{2}} t\right) \text { or } \\
& \ln (M R)=\ln \left(\frac{8}{\pi^{2}}\right)-\left(\frac{\pi^{2} \cdot D_{e}}{Y^{2}} t\right)
\end{aligned}
$$

The Arrhenius equation was used in order to quantify the activation energy (Gamboa-Santos et al., 2014):

$$
D_{e}=D_{o} \exp \left(\frac{-E_{a}}{R T}\right)
$$

The rehydration experiment of pretreated and untreated strawberries was conducted by immersing three slices of approximately $3 \mathrm{~g}$ in $20 \mathrm{ml}$ distilled water in a $50 \mathrm{ml}$ jar. The samples were rehydrated over a specified period of time at $40{ }^{\circ} \mathrm{C}$ of distilled water to evaluate the kinetics of water absorption. At every $5 \mathrm{~min}$, the samples were carefully removed from the jar, blotted with paper towel to remove excess water and weight. The moisture content $(\mathrm{X})$ was calculated at a specific time during rehydration according to Equation 1.

Color measurements in this experiment were performed using a three-filter colorimeter Konica Minolta CR-400. The color values obtained are presented in the CIE $L^{*} a * b *$ color space. In this color space, $L^{*}$ represents the brightness (illumination, lightness), whereas the coordinates $a^{*}$ and $b^{*}$ represent color. The negative value $a^{*}$ is green, and the positive $a^{*}$ is red. Negative $b^{*}$ is yellow, and the positive $b^{*}$ is blue (Alvarez-Fernandez, 2003). A combination of the illuminant and observer angle was $\mathrm{C} / 2^{\circ}$. The color measurements were conducted before and after convective drying. Samples are selected randomly. Ten measurements were performed for each sample. The values used for total color change calculations encompassed the average values of $L^{*}, a^{*}$ and $b^{*}$ of each sample. The color change in the samples during drying is presented by the total color change $\Delta \mathrm{E}$. It is calculated on the basis of the following equation (Alvarez-Fernandez, et. al., 2003):

$$
\Delta \mathrm{E}=\sqrt{\left(\mathrm{L}_{0}^{*}-\mathrm{L}^{*}\right)^{2}+\left(\mathrm{a}_{0}^{*}-\mathrm{a}^{*}\right)^{2}+\left(\mathrm{b}_{0}^{*}-\mathrm{b}^{*}\right)^{2}}
$$

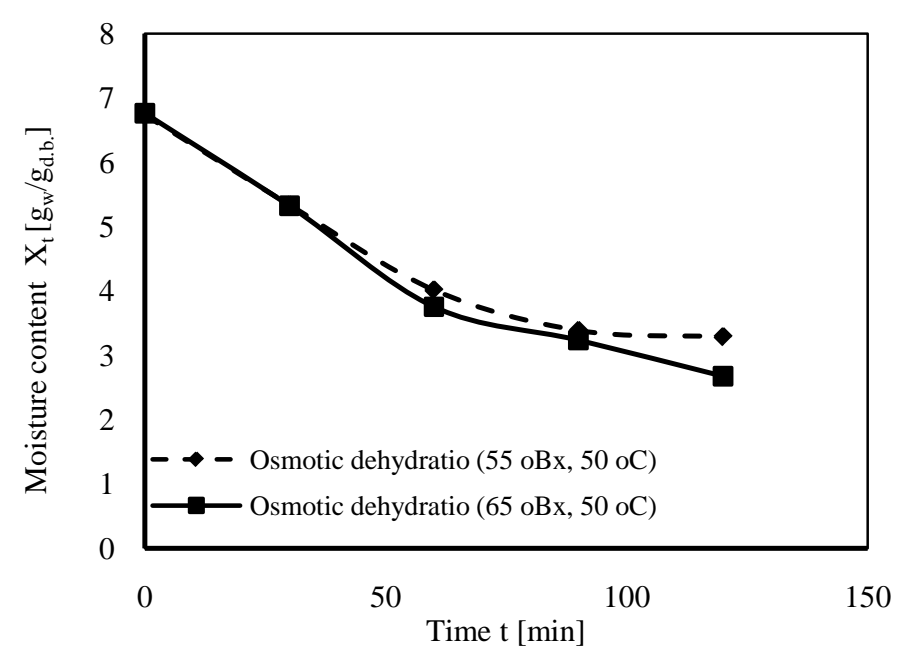

Fig. 1.Osmotic dehydration curves (moisture content versus drying time)

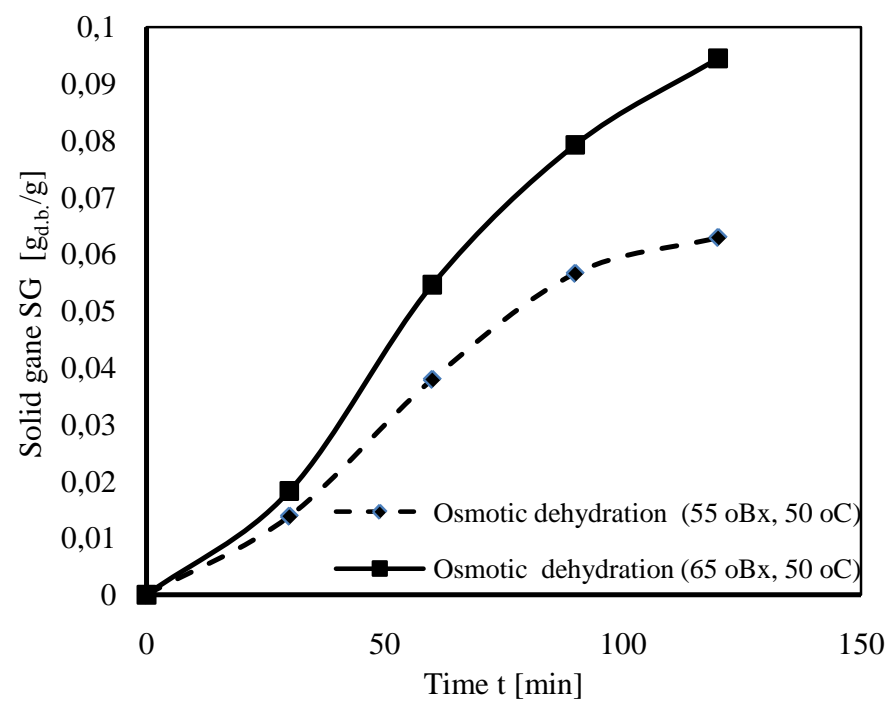

Fig.2.Osmotic dehydration curves (solid gain (SG) relative to drying time)

\section{RESULTS AND DISCUSSION}

Figures 1 and 2 show the drying curves which represent the variation of moisture and solid gain at different concentrations of osmotic solution and a constant temperature. The largest decrease in the moisture content at the end of dehydration was observed at the sucrose concentration of $65{ }^{\circ} \mathrm{Bx}\left(4.08 \mathrm{~g}_{\mathrm{w}} / \mathrm{g}_{\mathrm{db}}\right)$ and at the concentration of $50{ }^{\circ} \mathrm{Bx}\left(3.44 \mathrm{~g}_{\mathrm{w}} / \mathrm{g}_{\mathrm{db}}\right)$.

The greatest solid gain in strawberry tissue was observed at a concentration of $65{ }^{\circ} \mathrm{Bx}$ (SG $=0.0944 \mathrm{~g}_{\mathrm{dm}} / \mathrm{g}$ ). Higher concentrations of the solution have resulted in the appearance of large concentration gradient of water and solute molecules, i.e. the interface between the fruit tissue and osmotic solution. The membrane becomes more permeable to water molecules, which diffuse through the tissue more intensively towards the interface, lowering the resistance of the tissue to moisture diffusion.

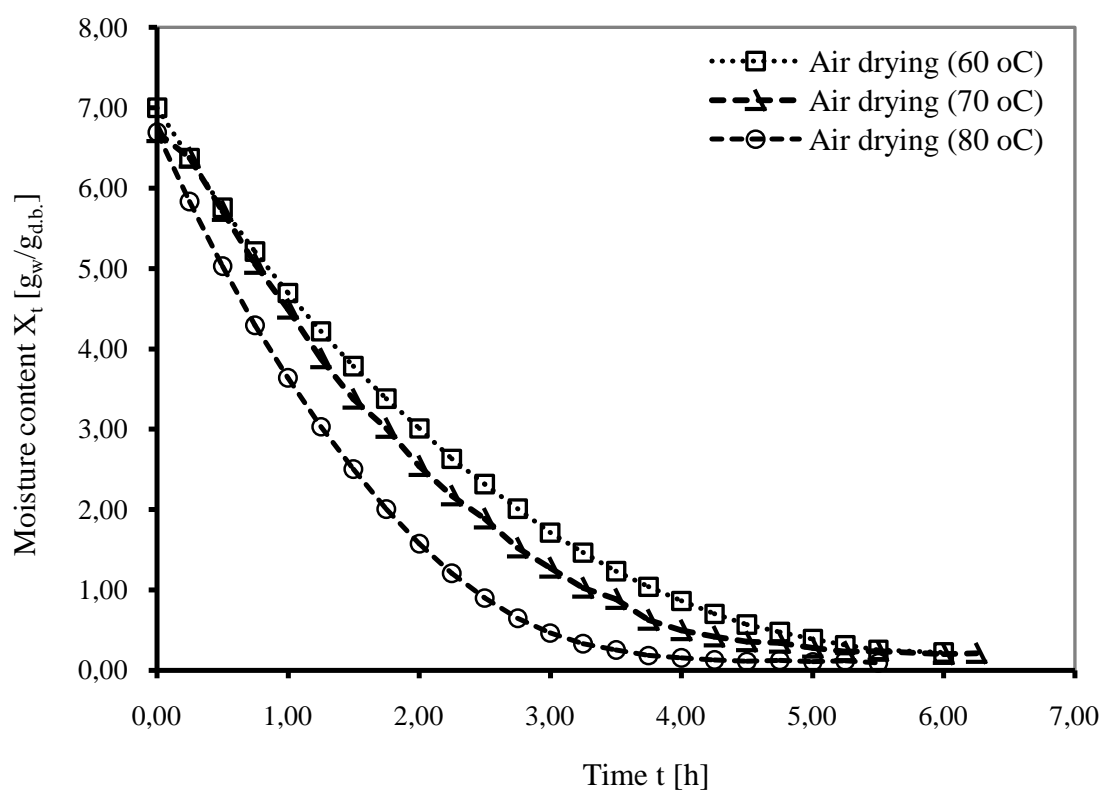

Fig. 3. Air drying curves for untreated strawberries $\left(60,70\right.$ and $\left.80^{\circ} \mathrm{C}\right)$ 


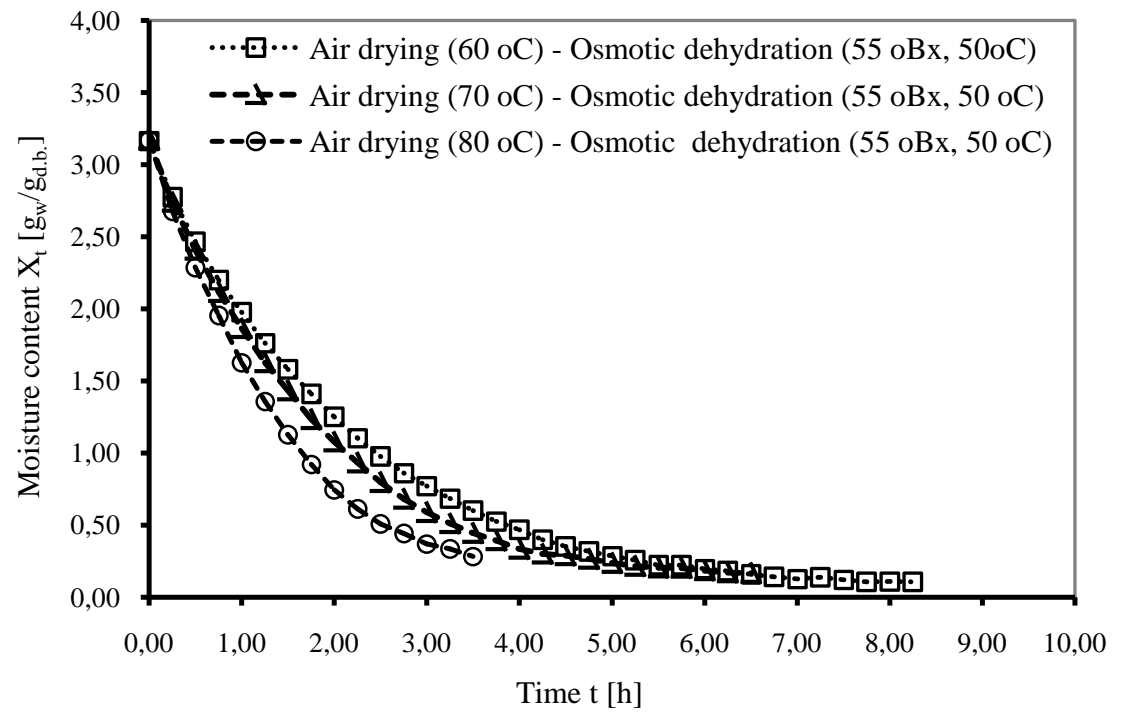

Fig. 4. Air drying curves $\left(60,70,80^{\circ} \mathrm{C}\right)$

for osmotically pretreated strawberries $\left(55^{\circ} \mathrm{Bx}, 50^{\circ} \mathrm{C}\right)$

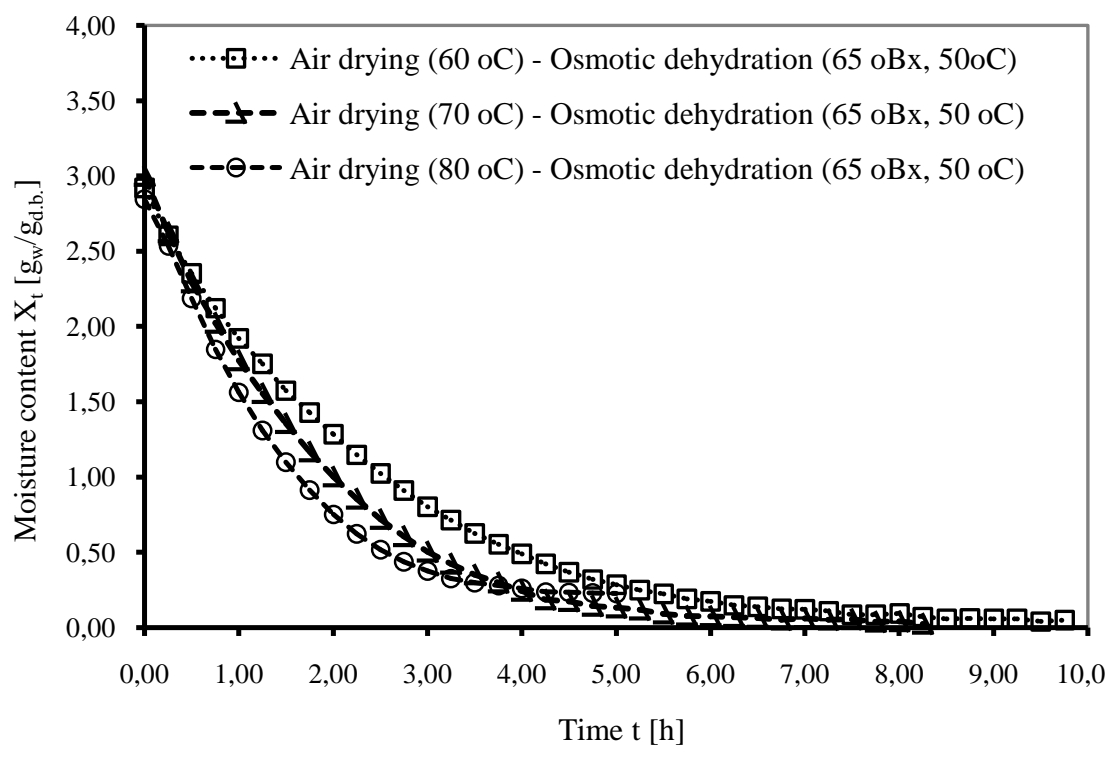

Fig. 5. Air drying curves $\left(60,70,80^{\circ} \mathrm{C}\right)$

for osmotically pretreated strawberries $\left(65^{\circ} \mathrm{Bx}, 50^{\circ} \mathrm{C}\right)$ $\left(60{ }^{\circ} \mathrm{C}\right), 4.75 \mathrm{~h}\left(70{ }^{\circ} \mathrm{C}\right)$ and $4.0 \mathrm{~h}\left(80{ }^{\circ} \mathrm{C}\right)$. Those results unequivocally demonstrate that the air drying time of untreated samples is shorter, but not significantly. Taking into account the total drying time (osmotic dehydration + air drying) in addition to $2 \mathrm{~h}$ required for osmotic dehydration, the drying process of pretreated samples is longer by approximately $26 \%$ to $32 \%$.

Variations in the drying rate and moisture content are shown in Fig. 2. A constant rate period was not observed in any of the experiments, whereas the entire strawberry drying process occurs in the range of the falling rate period. Analyzing the course of the drying rate curve for each experiment, it can be discerned that the draying rate grows with higher air temperatures. The maximum drying rate for the untreated samples, at an air temperature of $80^{\circ} \mathrm{C}$, was $0.0572 \mathrm{~g}_{\mathrm{w}} / \mathrm{g}_{\mathrm{dm}} \mathrm{min}$. These results are consistent with the results found in the literature (Pitrowski, D., et al., 2004, Doymaz, I., 2008)

The results of the air drying effective moisture diffusivity calculated for the nontreated and pretreated samples are shown in Table 1 . The effective moisture diffusivities of non-treated samples were higher than of the pretreated samples. The values of $D e$ increased with increasing air temperatures and decreased with increasing source concretions. The effective diffusivity varied from $8.20 \times 10^{-10}$ to $1.57 \times 10^{-9} \mathrm{~m}^{2} / \mathrm{s}$ in non-treated samples, from $4.43 \times 10^{-10}$ to $7.24 \times 10^{-10} \mathrm{~m}^{2} / \mathrm{s}$ in osmotically pretreated samples at a source concentration of $55^{\circ} \mathrm{Bx}$, and $4.54 \times 10^{-10}$ to $5.81 \times 10^{-10} \mathrm{~m}^{2} / \mathrm{s}$ at a source concentration $65{ }^{\circ} \mathrm{Bx}$. The values of $\mathrm{De}$ obtained in this study are within the general range of the reported diffusivities for strawberry drying (Doymaz, 2008; GamboaSantos, 2014). The values of activation energy were 31.23, 23.89 and $12.16 \mathrm{~kJ} / \mathrm{mol}$ in untreated and pretreated samples at $50{ }^{\circ} \mathrm{Bx}$ and $65{ }^{\circ} \mathrm{Bx}$, respectively. The influence of osmotic dehydration on the rehydration of air dried strawberries in comparison to air dried strawberries without osmotic dehydration is shown in Figure 7. After previous osmotic pretreatment, air dried strawberries were characterized by a lower water content after $75 \mathrm{~min}$ of rehydration compared to the samples which were not osmotically dehydrated. It was also noted that osmotic dehydration at a higher source concentration decreases the rehydration kinetics. In the non-treated samples, lower air temperatures increased the rehydration kinetics. The influence of air drying temperature on the rehydration kinetics of the pretreated samples is not significant. It was confirmed that the osmotic dehydration of strawberries caused the structure strengthening of air dried strawberries in comparison to fruit without osmotic pretreatment. After osmotic pretreatment, surface layers of the fruit were saturated by sucrose, which hindered the absorption of water and water vapor (Agnieszka and Lenart, 2010). 


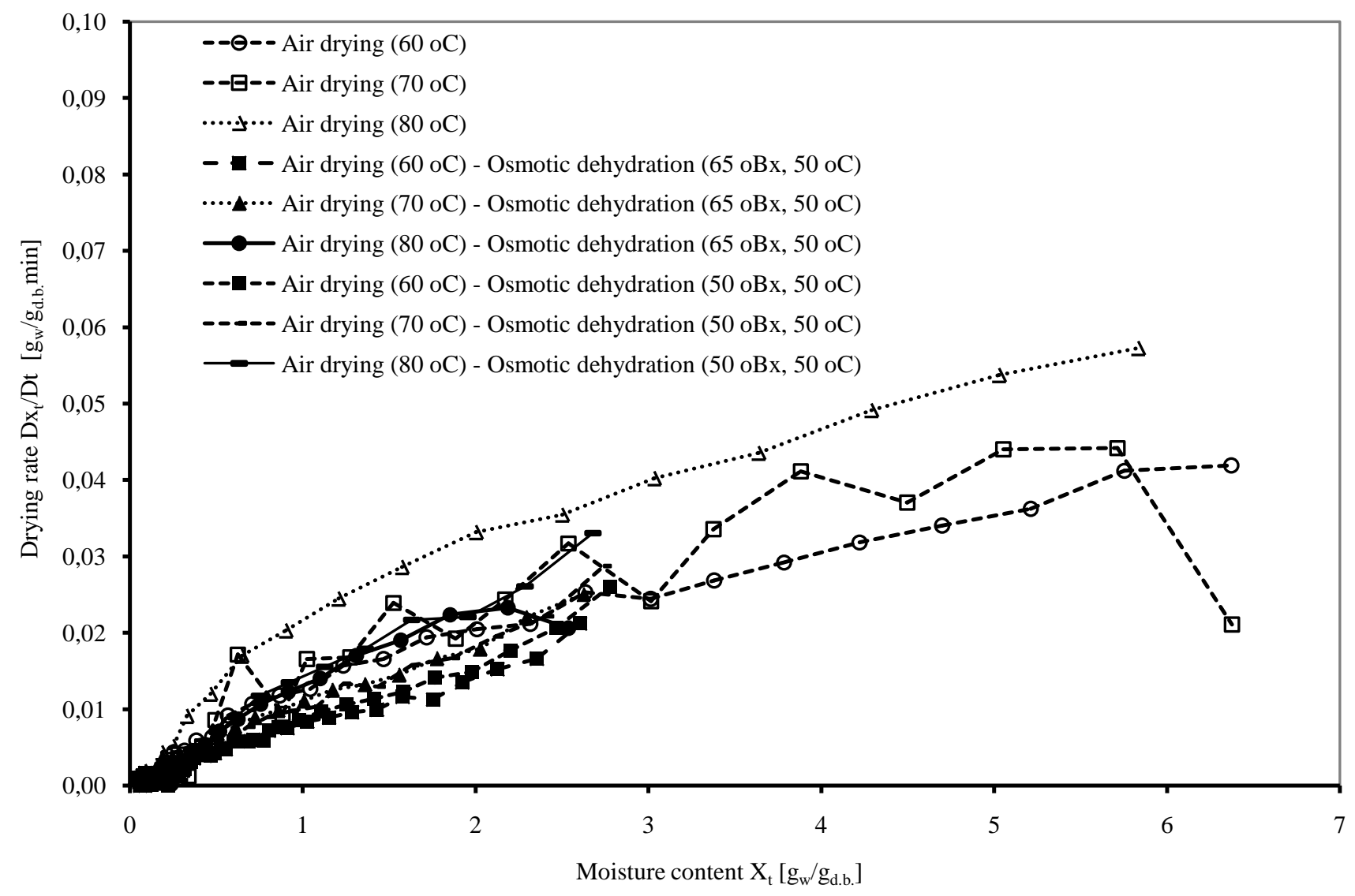

Fig. 6. Drying rate of untreated and osmotically pretreated strawberries

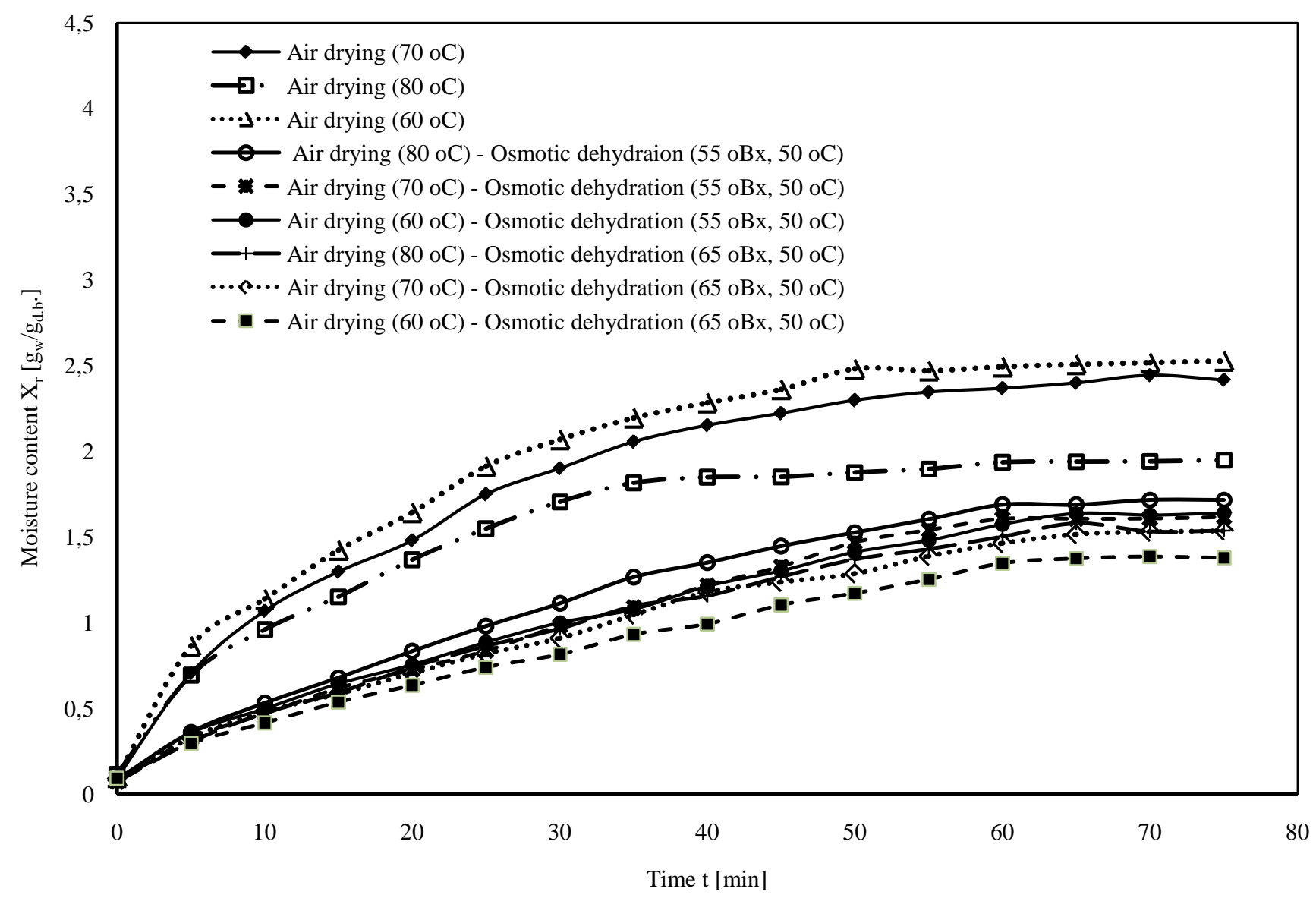

Fig.7. Influence of the air temperature and osmotic pretreatment on the moisture content as a function of the rehydration time 
Table 1. Calculated air drying effective moisture diffusivity for untreated and pretreated strawberry samples

\begin{tabular}{|c|c|c|c||}
\hline \hline No. & $\begin{array}{c}\text { Pretreatment } \\
\mathrm{C}\left[{ }^{\circ} \mathrm{Bx}\right], \mathrm{T}\left[{ }^{\circ} \mathrm{C}\right]\end{array}$ & $\begin{array}{c}\text { Air temperature } \\
\mathrm{T}\left[{ }^{\circ} \mathrm{C}\right]\end{array}$ & $\begin{array}{c}\text { Effective diffusivity } \\
\text { De }\left[\mathrm{m}^{2} / \mathrm{s}\right]\end{array}$ \\
\hline 1 & - & 60 & $8.29 \times 10^{-10}$ \\
\hline 2 & - & 70 & $1.02 \times 10^{-9}$ \\
\hline 3. & - & 80 & $1.57 \times 10^{-9}$ \\
\hline 4. & 55,50 & 60 & $4.43 \times 10^{-10}$ \\
\hline 5. & 55,50 & 70 & $4.87 \times 10^{-10}$ \\
\hline 6. & 55,50 & 80 & $7.24 \times 10^{-10}$ \\
\hline 7. & 65,50 & 60 & $4.54 \times 10^{-10}$ \\
\hline 8. & 65,50 & 70 & $5.75 \times 10^{-10}$ \\
\hline 9. & 65,50 & 80 & $5.81 \times 10^{-10}$ \\
\hline
\end{tabular}

According to the results shown in Fig. 8, significant changes in the total color are visible. The values of total color changes are between 12 and 26. There are no noticeable changes in the brightness value $\left(\Delta \mathrm{E}^{*}\right)$ between the treatments. The influence of osmotic pretreatment on changes in the strawberry color was not recorded. On balance, air temperatures exerted the most significant effects on the strawberry color. The greatest changes in the total strawberry color were measured in the samples dried at an air temperature of $60{ }^{\circ} \mathrm{C}$, which was noticeable in all the treatments. The values of these changes are significant, and range between 20 and $26 \Delta \mathrm{E}^{*}$. Such changes can be attributed to the longest period of convective drying at an air temperature of $60{ }^{\circ} \mathrm{C}$, which leads to an intensive fruit oxidation process.

\section{CONCLUSION}

The results obtained in this study indicate that osmotic dehydration in a sucrose solution, as a pretreatment of air drying, increases the drying time. Moreover, the rehydration of the untreated samples was faster than of the pretreated samples. It was found that there was not a constant rate period of air drying strawberry slices. Osmotically pretreated strawberries indicated lower values of the drying rate than the untreated samples. The effective moisture diffusivity varied from $1.57 \times 10^{-9}$ to $4.43 \times 10^{-}$ $10 \mathrm{~m} / \mathrm{s}^{2}$, increasing with an increase in air temperatures and decreasing with an increase in source concentrations. A shorter air drying process exerts a positive effect on the total color change in strawberries. The influence of pretreatment on the color changes in strawberries was not found to be significant after air drying.

ACKNOWLEDGMENT: This paper is result of the research within the project TR31058, 2011-2018, supported by the Ministry of Education, Science and Technology, Republic of Serbia.

\section{REFERENCES}

Adak, N., Heybeli, N., Ertekin, C. (2017). Infrared drying of strawberry. Food Chemistry, 219, 109-116.

Alvarez-Fernandez, Ana, Pilar, P., Abadiäa, J., Anunciacioän, A.(2003). Effects of Fe Deficiency Chlorosis on Yield and Fruit Quality in Peach (Prunuspersica L. Batsch). Journal of Agricultural and Food Chemistry, 51 (19), 5738-5744.

Crank, J. (1995). The mathematics of diffusion, $2^{\text {nd }}$ Ed., Clarendon Press, Oxford, U.K.

Ciurzynska, Agnieszka; Lenart, A. (2010).Rehydration and sorption properties of osmotically pretreated freeze-dried strawberries. Journal of Food Engineering, 97, 267-274

Dermesonlouoglou, E.K., Bimpilas, A., Varvara A., Katsaros, G.J., Giannakourou, M.C., Taoukis, P. (2016). Process optimization and kinetic modelling of quality of fresh-cut strawberry cubes pretreated by high pressure and osmosis.Journal of Food Processing and preservation, 1-14.

Doymaz, Ibrahim. (2008). Convective drying kinetics of strawberry. Chemical Engineering and Processing, 47, 914919.

Ferrando, M., Spiess, W.E.L. (2003).Mass Transfer in Strawberry Tissue During Osmotic Treatment I: Microstructural Changes. Food Engineering and physical properties, 68 (4), 1347-1355.

Gamboa-Santos, Juliana, Megías-Pérez, R., Soria, Cristina , Olano, A., Montilla, A., Villamiel, M. (2014). Impact of processing conditions on the kinetic of vitamin $\mathrm{C}$ degradation and 2furoylmethyl amino acid formation i dried strawberries. Food Chemistry, 153, 164-170.

Gamboa-Santos, Juliana, Montilla, Antonia, Andres carcel, J., Villamiel, M., Garcia-Perez, J.V. (2014).Air-borne ultrasound application in the convective drying of strawberry, Journal of Food Engineering, 128, 132-139.

Gerardo Barriada-Bernal. (2017). Convective drying kinetics of strawberry 
(Fragariaananassa): Effects on antioxidant activity, anthocyanins and total phenolic content. Food Chemistry, 230, 174-181.

Lilia Méndez-Lagunas, Juan Rodríguez-Ramírez, Marlene CruzGracida, Sadoth Sandoval-Torres ,

Meda, Laetitia, Ratti, Cristina. (2005). Rehydration of freezedried strawberries at varying temperatures. Journal of Food Process Engineering, 28, 233-246.

Pavkov, I., Babić, Ljiljana, Babić, M., Radojčin, M. (2009).Kinetics of the combined drying technology of pear slice (Pyrus). Journal on Processing and Energy in Agriculture (former PTEP), 13 (2), 111-116.

Pavkov I., Babić M., BabićLjiljana, Radojčin M., Stojanović Č (2010). Effects of Osmotic Dehydration Factors on Convective Drying Kinetics of Pears Slices (PyrusCommunis L.), Journal on Processing and Energy in Agriculture, 14(3), 125-130.

Pavkov I., Babić M., BabićLjiljana, Radojčin M., Stojanović Č. (2011). Effects of Osmotic Pre-Treatment on Convective Drying Kinetics of Nectarines Halfes (PyrusPersica L.), Jounal on Processing and Energy in Agriculture, 2011, 15(4), $217-$ 221.
Pavkov, I., Stamenković, Z., Radojčin, M., Babić, M., Bikić, S., Mitrevski, V., Lutovski, M.: Convective and Freeze Drying of Raspberry: Effect of Experimental Parameters on Drying Kinetics, Physical Properties and Rehydration Capacity. Proceedings of Fifth intenational Conference Sustainable Postharvest and Food Technologies - INOPTEP 2017, ISBN 978-86-7520-393-3, 23-28. april, 2017. Vršac, Republic of Serbia; 261-267.

Piotrowski, D., lenart, A., Wardzynski, A. (2004). Influence of osmotic dehydration on microwave-convective drying of frozen strawberries. Journal of Food Engineering, 65, 519-525.

Radojčin M., Babić M., BabićLjiljana, Pavkov I.: Color parameters change of quince during combined drying, Journal on Processing and Energy in Agriculture,, 2010, 14(2), 81-84.

Xin-feng Cheng, Zhang, M., Adhikari, B. (2014). Effect of Power Ultrasound and Pulsed vacuum treatments on the dehydration Kinetics, Distribution, and Status of Water in Osmotically dehydrated Strawberry: a Combined NMR and DSC Study. Food Bioprocess, 7, 2782-2792

Received: 26. 03. 2018.

Accepted: 29. 03. 2018. 